\title{
KOMPARASI ALGORITMA NEURAL NETWORK DAN NAÏVE BAYES UNTUK MEMPREDIKSI PENYAKIT JANTUNG
}

\author{
Hendri Mahmud Nawawi; Jajang Jaya Purnama²; Agung Baitul Hikmah ${ }^{3}$ \\ 1, 2 Program Studi Ilmu Komputer \\ STMIK Nusa Mandiri Jakarta \\ www.nusamandiri.ac.id \\ ${ }^{1}$ mahmudhend94@gmail.com, 2jajangja2412@bsi.ac.id \\ 3Program Studi Sistem Informasi \\ Universitas Bina Sarana Informatika \\ www.bsi.ac.id \\ agung.abl@bsi.ac.id
}

\begin{abstract}
Heart disease is one of the types of deadly diseases whose treatment must be dealt with as soon as possible because it can occur suddenly to the sufferer. Factors of heart disease that are recognized based on the condition of the body of a sufferer need to be known from an early age so that the risk of possible instant attacks can be minimized or can be overcome in various ways such as a healthy lifestyle and regular exercise that can regulate heart health in the body. By looking at the condition of a person's body based on sex, blood pressure, age, whether or not a smoker and some indicators that cause a person's affected by heart disease are described in a study using the Neural Network and Nä̈ve Bayes algorithm with the aim of comparing the level of accuracy to attributes influential to predict heart disease, so the results of this study can be used as a reference to predict whether a person has heart disease or not based on health data used as research benchmarks.
\end{abstract}

Keywords: Heart Disease, Neural Network Algorithm, Naïve Bayes Algorithm

Intisari- Penyakit jantung merupakan salah satu dari jenis penyakit mematikan yang penangannannya harus diatasi sesegera mungkin karena bisa terjadi secara mendadak kepada penderitanya. Faktor-faktor penyakit jantung yang dikenali berdasarkan kondisi tubuh seorang penderitanya perlu di ketahui sejak dini sehingga resiko kemungkinan terjadi serangan seketika bisa diminimalisir atau bisa diatasi dengan berbagai cara misalnya pola hidup sehat dan olahraga teratur yang bisa mengatur kesehatan jantung dalam tubuh. Dengan melihat kondisi tubuh seseorang berdasarkan jenis kelamin, tensi darah, usia, apakah perokok atau tidak dan beberapa indikator yang menjadi penyebab seseorang terkena penyakit jantung diuraikan dalam sebuah penelitian dengan menggunakan algoritma Neural Network dan Naïve Bayes dengan tujuan untuk membandingkan tingkat akurasi terhadap atribut berpengaruh untuk memprediksi penyakit jantung, sehingga hasil dari penelitian ini bisa dijadikan referensi untuk memprediksi apakah seseorang terkena penyakit jantung atau tidak berdasarkan data kesehatan yang dijadikan tolak ukur penelitian.

Kata Kunci : Penyakit Jantung, Neural Network, Naïve Bayes

\section{PENDAHULUAN}

Dunia kesehatan memiliki database yang sangat banyak untuk dijadikan bahan penelitian bagi dunia pendidikan. Namun dataset yang tersedia biasanya hanya digunakan sebagai arsip misalnya data hasil cek Lab atau hasil pemeriksaan pasien yang menderita gejala atau penyakit tertentu. Arsip tersebut akan sangat bermanfaat apabila dapat digunakan dan diolah dengan baik dan tepat hal ini bertujuan untuk mempelajari kejadian dimasa lalu untuk dijadikan pertimbangan dimasa yang akan datang apabila terjadi kasus atau kejadian yang sama dengan data kesehatan yang sama sehingga efisiensi pendeteksian penyakit bisa diketahui sedini mungkin. Penulis tertarik untuk membuat artikel tentang prediksi penyakit jantung yang merupakan salah satu jenis penyakit mematikan dengan melakukan analisa terhadap gejala-gejala dan data kesehatan tubuh dari penyakit jantung yang diperoleh dari data publik dengan tujuan untuk mempresentasikan dengan data kesehatan yang telah dianalisa apakah sesuai antara prediksi yang dihasilkan dari perhitungan dengan menggunakan machine learning berdasarkan algoritma Neural Network dan Algoritma Naïve Bayes yang penulis gunakan pada penelitian ini dengan prediksi sesungguhnya dari hasil cek lab. Penulis melakukan komparasi atau perbandingan antara algoritma Neural Network dengan Algoritma Naïve Bayes dengan tujuan untuk membandingkan algoritma mana yang paling relevan dan nilai akurasinya paling tinggi untuk mendeteksi penyakit jantung berdasarkan 14 attribut input, pada algoritma Naïve Bayes penulis menambahkan optimasi. Naïve 
Bayes Classifier perlu dioptimasi dengan cara memberikan bobot pada atribut agar naïve bayes classifier dapat bekerja lebih efektif (Muhamad et al., 2017) sedangkan pada algoritma Neural Network penulis menggunakan backpropagation.

Penyakit jantung merupakan penyakit yang sangat berbahaya dan merupakan penyakit pembunuh nomor satu di dunia, oleh karena itu penting diketahui ciri-ciri penyakit jantung agar dapat ditanggulangi sejak dini (dedaunan.com, 2019). Beberapa faktor yang dapat menyebabkan penyakit jantung umumnya adalah kebiasaan hidup tidak sehat, merokok, begadang dan pola makan yang tidak baik. Penyebab utama penyakit jantung adalah penggunaan tembakau, fisik tidak aktif, diet yang tidak sehat dan penggunaan alkohol, meningkatnya usia, tekanan darah tinggi, mempunyai kolesterol tinggi, dan kelebihan berat badan (Lestari, 2014).

Untuk melakukan prediksi beberapa faktor yang telah disebutkan diatas dapat dambil kesimpulan bahwasanya penyakit jantung merupakan penyakit yang banyak penyebabnya dan penyebab tersebut bisa saja kegiatan yang selama ini tanpa kita sadari terbiasa melakukannya, untuk itu beberapa penyebab tersebut dirumuskan kedalam sebuah tabel yang merangkum faktor penyebab seseorang terkena penyakit jantung. Data dari tabel tersebut diolah menjadi data training untuk diolah kedalam machine learning, agar memudahkan dalam perhitungan dan mendapatkan nilai akurasi dan prediksi yang baik penulis menggunakan dua metode berbeda untuk melakukan prediksi dan membandingkan akurasi terhadap penyakit jantung tersebut yaitu algoritma neural network dan naïve bayes.

\section{BAHAN DAN METODE}

Untuk mencapai tujuan penelitian sebuah metodologi penelitian perlu dikembangkan, pada tulisan ini penulis menggunakan model estimasi berbasis ANN untuk pengujian data validasi hasil dari tahap training dan algoritma naïve bayes untuk melihat perbedaan nilai akurasi yang dihasilkan. Bayes memiliki akurasi dan kecepatan yang sangat tinggi saat diaplikasi ke dalam database dengan data yang besar (Widiastuti, Santosa, \& Supriyanto, 2014).

Dalam buku Heaton Neural Network adalah jaringan saraf yang mensimulasikan jaringan saraf biologis manusia kedalam arsitektur computer dan arsistektur algoritma baru terhadap computer konvensional. Hal ini memungkinkan penggunaan operasi komputasi (penambahan, pengurangan, dan elemen logika fundamental) yang sangat sederhana untuk memecahkan masalah yang kompleks, matematis yang tidak jelas, masalah nonlinear atau masalah stokastik (Yunita, 2015).

Sebagaimana kita ketahui bahwa peramalan merupakan dugaan atau prediksi terhadap kejadian yang akan datang setelah mempelajari kejadian dimasa lalu atau kejadian yang pernah dialami sebelumnya. Peramalan juga bisa digunakan dalam aktivitas bisnis dimana dapat memperkirakan jumlah penjualan dan penggunaan produk di periode yang akan datang, sehingga produk dapat dibuat dalam kuantitas yang tepat sesuai dengan hasil peramalan (Habibi \& Riksakomara, 2017).

Perubahan terjadi jika tidak diantisipasi, hasilnya bisa menjadi bencana. Suatu perusahaan mempersiapkan untuk perubahan dengan perencanaan, yang pada gilirannya memerlukan pembuatan perkiraan, menetapkan tujuan berdasarkan perkiraan dan menentukan bagaimana busur tujuan untuk dihubungi. Singkatnya, peramalan merupakan bagian integral dari proses perencanaan (Kusumodestoni \& Zyen, 2015).

Dalam peramalan, untuk mendapatkan hasil yang akurat dan bermanfaat, terdapat dua hal yang harus diperhatikan :

1. Data yang dikumpulkan haruslah berupa informasi yang revelan sehingga dapat menghasilkan peramalan yang akurat.

2. Penggunaan metode peramalan yang tepat (Habibi \& Riksakomara, 2017)

Secara umum peramalan dengan metode neural network backpropaganda adalah sebagai berikut dimana terdiri dari 3 neuron atau layer yaitu layer input, layer dan layer output.

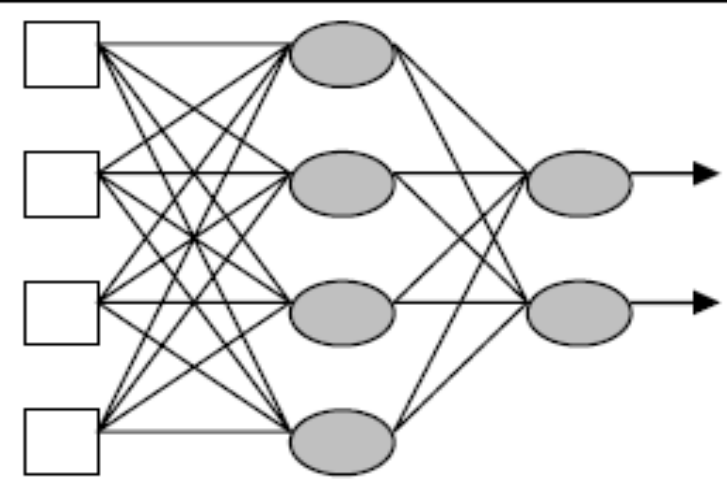

Layer input Layer Layer output

Sumber: (Effendy, Subagja, \& Faisal, 2008)

Gambar 1 Konsep Jaringan Sarap Tiruan Backpropagation

Alur penyelesaian algoritma pelatihan JST - BP adalah sebagai berikut

1. Definisi masalah, misalkan matriks masukan $(P)$ dan matriks target $(T)$.

2. Inisialisasi, menentukan bentuk jaringan dan menetapkan nilai-nilai bobot sinaptik $W 1$ dan $W 2$, dan learning rate (Ir).

3. Pelatihan Jaringan : 
a. Perhitungan Maju Galat (E) merupakan selisih antara nilai keluaran yang diinginkan (T) dengan keluaran yang sesungguhnya (A2), sebagai berikut :

$E=T A r^{2}$

Sum Square Error (SSE) yang dinyatakan oleh persamaan berikut :

$\mathrm{SSE}=\sum E^{2}$

b. Perhitungan Balik

$D 2=A 2(1-A 2) E$

$\mathrm{dW} 2=\mathrm{dW} 2+\left(\operatorname{lr} \times \mathrm{D} 2 \times \mathrm{A}_{1}\right)$

$\mathrm{D} 1=\mathrm{A}_{1}\left(1-\mathrm{A}_{1}\right) \times(\mathrm{W} 2 \times \mathrm{D} 2)$

$\mathrm{dW} 1=\mathrm{dW} 1+(\operatorname{lr} \times \mathrm{D} 1 \times \mathrm{P})$

c. Perbaikan Bobot Jaringan

$T W 2=W 2+d W 2$

$\mathrm{TW} 1=\mathrm{W} 1=\mathrm{dW} 1$

$\mathrm{W} 2=\mathrm{TW} 2$

$\mathrm{W} 1=\mathrm{TW} 1$

Keluaran untuk lapisan tersembunyi

$$
A 1=\frac{1}{-\sum_{\substack{i=1 \\ 1+\in}}^{n}(P 1) x \quad W 1^{j i}}
$$

Hasil keluaran lapisan tersembunyi dipakai untuk mendapatkan lapisan keluaran :

$$
\begin{aligned}
& A 1=\frac{1}{-\sum_{i=1}^{n}(A i j) x \quad W 2^{j i}} \\
& 1+\mathrm{E}
\end{aligned}
$$

4. Langkah-langkah di atas adalah untuk satu kali siklus pelatihan (satu epoch), sehingga harus diulang-ulang sampai jumlah epoch yang ditentukan atau telah tercapai SSE (Sum Square Error) yang diinginkan.

5. Hasil akhir pelatihan jaringan adalah didapatkannya bobot $W 1$ dan $W 2$ yang kemudian disimpan untuk pengujian jaringan. (Effendy et al., 2008)

\section{Metode Naive Bayes}

Naive bayes merupakan salah satu metode statistik untuk klasifikasi yang memungkinkan untuk menangkap ketidakpastian tentang suatu model dengan cara berprinsip pada mendefinisikan hasil probabilitas. Metode ini digunakan untuk menyelesaikan masalah diagnosa dan prediksi (Supriyatna \& Mustika, 2018). Definisi lain mengatakan Naive Bayes merupakan pengklasifikasian dengan metode probabilitas dan statistik yang dikemukakan oleh ilmuan Inggris Thomas Bayes, yaitu memprediksi peluang di masa depan berdasarkan pengalaman di masa sebelumnya. Teorema Bayes memiliki bentuk umum sebagai berikut:
$\mathrm{P}(\mathrm{H} \mid \mathrm{X})=\frac{P(x \mid H) \cdot P(H)}{P(x)}$

Dimana :

$\mathrm{X}=$ Data dengan class yang belum diketahui.

$\mathrm{H} \quad=$ Hipotesis Data X merupakan suatu class spesifik

$\mathrm{P}(\mathrm{H} \mid \mathrm{X})=$ probabilitas hipotesis $\mathrm{H}$ berdasarkan

kondisi $\mathrm{x}$ (posteriori prob.)

$\mathrm{P}(\mathrm{H})=$ Probabilitas hipotesis $\mathrm{H}$ (prior prob.)

$\mathrm{P}(\mathrm{X} \mid \mathrm{H})=$ probabilitas $\mathrm{X}$ berdasarkan kondisi tersebut

$\mathrm{P}(\mathrm{X})=$ probabilitas dari $\mathrm{X}$

Umumnya, Bayes mudah dihitung untuk fitur

bertipe kategoris seperti pada kasus fitur "jenis kelamin" dengan nilai \{pria, wanita\} namun untuk fitur numerik ada perlakuan khusus sebelum dimasukkan dalam Naive Bayes. Caranya adalah

a. Melakukan diskretisasi pada setiap fitur kontinu dan mengganti nilai fitur kontinu tersebut dengan nilai interval diskret. Pendekatan ini dilakukan dengan mentransformasikan fitur kontinu ke dalam fitur ordinal.

b. Mengasumsikan bentuk tertentu dari distribusi probabilitas untuk fitur kontinu dan memperkirakan parameter distribusi dengan data pelatihan. Distribusi Gaussian sering dipilih untuk merepresentasikan peluang kelas bersyarat untuk atribut kontinu. Distribusi dikarakterisasi dengan dua parameter yaitu mean, $\mu$, dan varian, $\sigma^{2}$. untuk tiap kelas $y_{j}$, peluang kelas bersyarat untuk atribut $\mathrm{x}_{\mathrm{i}}$ adalah:

$P(X 1=x 1 \mid Y=y 1))=\frac{1}{\sqrt{2 \pi \sigma i j}} \exp (x 1-\mu) 2 \ldots$

Dimana :

$\mathrm{P} \quad$ : Peluang

$\mathrm{Xi}$ : Atribut ke i

$\mathrm{xi} \quad$ : Nilai atribut ke i

Y : Kelas yang dicari

Yi : sub kelas Y yang dicari

$\mu$ : Mean, menyatakan varian dari seluruh atribut

$\sigma$ : deviasi standar, menyatakan varian dari seluruh atribut (Supriyatna \& Mustika, 2018).

\section{Nilai AUC}

Nilai AUC pada data mining dibagi menjadi beberapa kelompok yaitu sangat baik untuk nilai 0.901.00, klasifikasi baik untuk nilai 0.80-0.90, klasifikasi cukup untuk nilai 0.70-0.80, klasifikasi buruk untuk nilai 0.60-0.70 dan klasifikasi salah untuk nilai 0.500.60 (Lestari, 2014).

\section{HASIL DAN PEMBAHASAN}

Objek permasalahan mengenai penyakit jantung yang diperoleh dari dataset global UCI Repository membuat klasifikasi ciri-ciri penderita yang terkena 
penyakit jantung berdasarkan 14 attribut, attribut tersebut diolah dengan algoritma neural network dan naïve bayes. Berikut adalah kriteria-kriteria yang yang dijadikan attribute sebagai prediksi terhadap pasien penderita penyakit jantung.

1. Usia : usia dituliskan dalam bentuk angka numerical

2. Gender : dituliskan 1 untuk "laki-laki' dan 0 untuk "perempuan"

3. Type nyeri dada berdasarkan gejala-gejala khas angina, angina atipikal, nyeri non-angina dan tanpa gejala

4. $\mathrm{Tb}$ : Tekanan darah saat istirahat (dihitung $\mathrm{mm} \mathrm{Hg}$ saat masuk ke rumah sakit)

5. Kol : serum kolestoral dalam mg / dl

6. Fbs : nilai 1 jika "Ya" dan 0 jika "Tidak"

7. Restecg : beristirahat hasil elektrokardiografi

- Nilai 0: normal

- Nilai 1: memiliki kelainan gelombang ST-T (inversi gelombang $\mathrm{T}$ dan / atau elevasi atau depresi ST>0,05 mV)

- $\quad$ Nilai 2: menunjukkan hipertrofi ventrikel kiri yang mungkin atau pasti berdasarkan kriteria Estes

8. Thalach: denyut jantung maksimum tercapai

9. Exang : olahraga yang diinduksi angina $(1=$ ya; $0=$ tidak)

10. Oldpeak : ST depresi yang disebabkan oleh olahraga relatif terhadap istirahat

11. Slope : kemiringan segmen ST latihan puncak

- Nilai 1: menanjak

- Nilai 2: datar

- Nilai 3: downsloping

12. Ca: jumlah kapal utama (0-3) diwarnai oleh flourosopy

13. Thal : $3=$ normal; $6=$ cacat tetap; $7=$ cacat yang dapat dibalik

14. Predikisi attribute

Tabel 1 Data Training

\begin{tabular}{|c|c|c|c|c|c|c|c|c|c|c|c|c|c|}
\hline $\begin{array}{l}\text { Us } \\
\text { ia }\end{array}$ & $\begin{array}{l}\mathrm{G} \\
\mathrm{e} \\
\mathrm{n}\end{array}$ & $\begin{array}{l}\mathrm{C} \\
\mathrm{p}\end{array}$ & $\begin{array}{c}\text { Bp } \\
\mathrm{s}\end{array}$ & $\begin{array}{l}\mathrm{C} \\
\mathrm{h} \\
\mathrm{o} \\
\mathrm{l}\end{array}$ & $\begin{array}{l}\mathrm{F} \\
\mathrm{b} \\
\mathrm{s}\end{array}$ & $\begin{array}{c}\text { Res } \\
\text { tec } \\
\mathrm{g}\end{array}$ & $\begin{array}{l}\text { Tha } \\
\text { lac }\end{array}$ & $\begin{array}{l}E \\
x \\
a\end{array}$ & $\begin{array}{c}\text { Old } \\
p\end{array}$ & $\begin{array}{l}\mathrm{S} \\
\mathrm{l} \\
\mathrm{o} \\
\mathrm{p}\end{array}$ & $\begin{array}{l}\mathrm{C} \\
\mathrm{a}\end{array}$ & $\begin{array}{l}\mathrm{T} \\
\mathrm{h} \\
\mathrm{a} \\
\mathrm{l}\end{array}$ & $\begin{array}{c}\text { Pre } \\
\text { d }\end{array}$ \\
\hline 63 & 1 & 1 & $\begin{array}{c}14 \\
5\end{array}$ & $\begin{array}{l}2 \\
3 \\
3 \\
\end{array}$ & 1 & 2 & 150 & 0 & 2,3 & 3 & 0 & 0 & 0 \\
\hline 67 & 1 & 4 & $\begin{array}{c}16 \\
0\end{array}$ & $\begin{array}{l}2 \\
8 \\
6 \\
\end{array}$ & 0 & 2 & 108 & 1 & 1,5 & 2 & 3 & 3 & 2 \\
\hline 67 & 1 & 4 & $\begin{array}{c}12 \\
0\end{array}$ & $\begin{array}{l}2 \\
2 \\
9\end{array}$ & 0 & 2 & 129 & 1 & 2,6 & 2 & 2 & 2 & 1 \\
\hline 37 & 1 & 3 & $\begin{array}{c}13 \\
0\end{array}$ & $\begin{array}{l}2 \\
5 \\
0\end{array}$ & 0 & 0 & 187 & 0 & 3,5 & 3 & 0 & 0 & 0 \\
\hline$\ldots$ & $\ldots$ & $\ldots$ & $\ldots$ & $\ldots$ & $\ldots$ & $\ldots$ & $\ldots$ & $\ldots$ & $\ldots$ & .. & $\ldots$ & .. & .. \\
\hline 37 & 0 & 2 & $\begin{array}{c}12 \\
0\end{array}$ & $\begin{array}{l}2 \\
0 \\
4 \\
\end{array}$ & 0 & 2 & 172 & 1 & 1,4 & 1 & 0 & 0 & 0 \\
\hline 65 & 1 & 1 & $\begin{array}{c}13 \\
0\end{array}$ & $\begin{array}{l}2 \\
5 \\
5 \\
\end{array}$ & 1 & 1 & 178 & 1 & 0,8 & 1 & 2 & 0 & 2 \\
\hline
\end{tabular}

Sumber : (Nawawi, Purnama, \& Hikmah, 2019)

Dari tabel diatas direpresentasikan kedalam sebuah metode algoritma Neural Network dan Naïve
Bayes untuk melihat perbandingan algoritma mana yang memiliki akurasi tertinggi. Dengan metode jaringan sarap tiruan backpropagation 14 attribute tersebut diolah kedalam machine learning rapid miner.

Berdasarkan hasil pengolahan 14 attribut dihasilkan jaringan sarap tiruan berupa neuron sebagai berikut

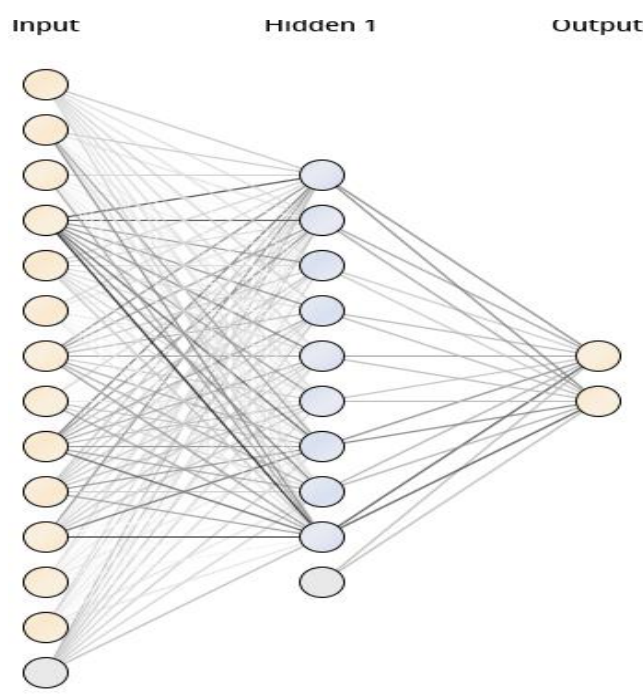

Sumber: (Nawawi et al., 2019)

Gambar 2 Output Jaringan Sarap Tiruan Backpropagation

Dari gambar diatas bisa dilihat bahwa dengan merancang nilai inputan (Layer input) sebanyak 14 atribut atau 14 elemen pemrosesan (neuron) yang sesuai dengan 14 parameter tersebut dihasilkan dua nilai output setelah dilakukan percobaan sebanyak 10 (sepuluh) kali (hidden layer) selama tahap pengujian.

Konfigurasi JST yang digunakan untuk menghasilkan output tersebut berdasarkan 14 parameter input adalah sebagai berikut:

Tabel 2 Parameter JST

\begin{tabular}{lc}
\hline \multicolumn{1}{c}{ Parameter } & Nilai \\
\hline Jumlah sel lapisan masuk & 14 \\
\hline $\begin{array}{l}\text { Jumlah sel lapisan tersembunyi } \\
\text { (hidden 1) }\end{array}$ & 10 \\
\hline Jumlah sel lapisan keluaran & 2 \\
\hline $\begin{array}{l}\text { Maksimum pelatihan (training } \\
\text { cycle) }\end{array}$ & 200 \\
\hline Learning Rate & 0,01 \\
\hline Momentum & 0,9 \\
\hline Performance Goal & $1.0 \mathrm{E}-4$ \\
\hline $\begin{array}{l}\text { Sumber : (Nawawi et al., 2019) } \\
\text { Berdasarkan nilai inputan diatas untuk }\end{array}$
\end{tabular}
prediksi penyakit jantung dengan menggunakan 14 attribut diperoleh nilai akurasi sebesar 84,52 \% dengan rata-rata terkecil adalah 84,49\%.

Selanjutnya untuk melihat perbandingan dengan metode algoritma Naïve Bayes atribut-atribut 
tesebut dianalisa dan disajikan dengan data numerik menggunakan Distrbusi Gaussian untuk mencari nilai mean dan varian yang diklasifikasikan menurut kelasnya. Rata-rata dan standar deviasi dihitung setiap attributnya. Sehingga diperoleh nilai sebagai berikut :

Tabel 3 Parameter Naïve Bayes

\begin{tabular}{|c|c|c|c|c|}
\hline \multirow{3}{*}{ Attribute } & \multicolumn{4}{|c|}{ Parameter } \\
\hline & \multicolumn{2}{|c|}{ Mean } & \multicolumn{2}{|c|}{ Standar Deviasi } \\
\hline & 1 & $\mathbf{0}$ & 1 & $\mathbf{0}$ \\
\hline Usia & 57 & 53,992 & 7,061 & 9,280 \\
\hline Gender & 0,733 & 0,671 & 0,447 & 0,471 \\
\hline $\begin{array}{l}\text { Type nyeri } \\
\text { dada }\end{array}$ & 3,067 & 3,174 & 0,986 & 0,957 \\
\hline TB & 139,067 & 130,403 & 20,163 & 16,828 \\
\hline Kol & 247,911 & 246,481 & 51,116 & 51,987 \\
\hline Restecg & 1,156 & 0,961 & 0,999 & 0,993 \\
\hline Thalac & 149,178 & 149,682 & 22,227 & 23,027 \\
\hline Exang & 0,356 & 0,322 & 0,484 & 0,468 \\
\hline Oldpeak & 1,056 & 1,037 & 1,072 & 1,178 \\
\hline Slope & 1,689 & 1,585 & 0,701 & 0,600 \\
\hline $\mathrm{Ca}$ & 0,978 & 0,609 & 1,076 & 0,898 \\
\hline Thal & 5,089 & 4,659 & 1,917 & 1,957 \\
\hline Pred & 1,111 & 0,907 & 1,283 & 1,219 \\
\hline
\end{tabular}

Sumber : (Nawawi et al., 2019)

Berdasarkan parameter-parameter diatas dari data training yang diolah menggunakan perhitungan algoritma Naïve Bayes dengan ditambahkan optimasi diperoleh nilai akurasi sebesar 79,88\% dengan nilai rata-rata minimum sebesar $79,87 \%$.

Selanjutnya untuk melihat perbandingan antara algoritma neural network JST Backpropagation dengan Naïve Bayes klasifikasi dari 14 atribut yang dijadikan parameter untuk memprediksi penyakit jantung bisa dilihat perbandingannya pada tabel berikut:

Tabel 4 Perbandingan Algoritma Neural Network dengan Naïve Bayes

\begin{tabular}{lcc}
\hline & Neural Network & Naïve Bayes \\
\hline Akurasi & $84,52 \%$ & $79,88 \%$ \\
\hline Presisi & $85,31 \%$ & $85,86 \%$ \\
\hline Recall & $98,85 \%$ & $91,45 \%$ \\
\hline $\begin{array}{l}\text { AUC } \\
\text { (optimistis) }\end{array}$ & 0,601 & 0,577 \\
\hline AUC & 0,601 & 0,577 \\
\hline $\begin{array}{l}\text { AUC } \\
\text { (Pesimistis) }\end{array}$ & 0,601 & 0,577 \\
\hline
\end{tabular}

Sumber: (Nawawi et al., 2019)

Dari table 4 diatas prediksi penyakit jantung dengan 14 atribut Usia, Gender, Tb, Kol, Fbs, Restecg, Thalach, Exang, Oldpeak, Slope, $\mathrm{Ca}$, Thal bisa dijadikan sebagai tolak ukur untuk memprediksi kesehatan jantung seseorang dengan akurasi 84,52\% menggunakan algoritma Neural Network backpropagation dan 79,88\% menggunakan algoritma
Naïve Bayes menggunakan optimasi dan ini menunjukan bahwa dengan 14 attribut yang sama untuk memprediksi penyakit jantung algoritma neural network jauh lebih baik daripada algoritma Naïve Bayes dengan Nilai AUC pada Algoritma Neural Network sebesar 0,601\% (klasifikasi buruk) sedangkan pada Algoritma Naïve Bayes 0,577\% (klasifikasi salah).

\section{KESIMPULAN}

Dari perbandingan kedua algoritma Neural Network dan Naïve Bayes untuk melakukan prediksi terhadap penyakit jantung dengan 14 atribut hasilnya lebih dari $75 \%$ tepat untuk mendeteksi penyakit jantung pada manusia hal ini bisa dijadikan tolak ukur untuk menjadi perhatian kepada orang yang memiliki data kesehatan berdasarkan data training diatas, namun meskipun memliki akurasi yang baik, Algoritma Neural Network dan Algoritma Naïve Bayes memiliki nilai klasifikasi AUC yang buruk dan salah hal ini perlu dilakukan penelitian lebih lanjut misalnya dengan menambahkan beberapa atribut lain yang berhubungan dengan penyakit jantung sehingga akurasi dan nilai AUC nya sesuai harapan yaitu akurasi yang baik diperoleh dari klasifikasi yang baik juga.

\section{REFERENSI}

dedaunan.com. (2019). Ciri-Ciri Penyakit Jantung yang Wajib Anda Ketahui. Retrieved from https://dedaunan.com/ciri-ciri-penyakitjantung-yang-wajib-anda-ketahui/

Effendy, N., Subagja, \& Faisal, A. (2008). Prediksi penyakit jantung koroner ( PJK ) berdasarkan faktor risiko menggunakan jaringan syaraf tiruan backpropagation. Seminar Nasional Aplikasi Teknologi Informasi 2008 (SNATI 2008), (January), E19-E24.

Habibi, M. Y. (Institut S. M., \& Riksakomara, E. I. S. M. (2017). Peramalan Harga Garam Konsumsi Menggunakan Artificial Neural Network Feedforward-Backpropagation ( Studi Kasus: 6(2), A306-A310.

Kusumodestoni, R. H., \& Zyen, A. K. (2015). PREDIKSI KECEPATAN ANGIN MENGGUNAKAN MODEL NEURAL NETWORK UNTUK MENGHETAHUI BESAR DAYA LISTRIK YANG DIHASILKAN. Jurnal DISPROTEK, 6(1), 53-39.

Lestari, M. E. I. (2014). PENERAPAN ALGORITMA KLASIFIKASI NEAREST NEIGHBOR ( K-NN ) UNTUK MENDETEKSI PENYAKIT JANTUNG. Faktor Exacta, 7(September 2010), 366-371. 
Muhamad, H., Prasojo, C. A., Sugianto, N. A., Surtiningsih, L., Cholissodin, I., Ilmu, F., ... Optimization, P. S. (2017). OPTIMASI NAÏVE BAYES CLASSIFIER DENGAN MENGGUNAKAN PARTICLE. Jurnal Teknologi Informasi Dan Ilmu Komputer (JTIIK), 4(3), 180-184.

Nawawi, H. M., Purnama, J. J., \& Hikmah, A. B. (2019). KOMPARASI ALGORITMA NEURAL NETWORK DAN NAÏVE BAYES UNTUK MEMPREDIKSI PENYAKIT JANTUNG. Jurnal PILAR Nusa Mandiri.

Supriyatna, A., \& Mustika, W. P. (2018). Komparasi Algoritma Naive bayes dan SVM Untuk Memprediksi Keberhasilan Imunoterapi Pada Penyakit Kutil. Jurnal Sains Komputer \& Informatika (J-SAKTI), Volume (2)(2), 152-161.

Widiastuti, N. A., Santosa, S., \& Supriyanto, C. (2014). ALGORITMA KLASIFIKASI DATA MINING NAÏVE BAYES BERBASIS PARTICLE SWARM. Jurnal Pseudocode, Volme 1 No, 11-14.

Yunita. (2015). Prediksi Cuaca Menggunakan Metode Neural Network. PARADIGMA VOL. XVII NO. 2 MARET 2015, XVII(2), 47-53. 